Highlighted article

\title{
Contaminant fate and transport in the Venice Lagoon: Results from a multi-segment multimedia model
}

\author{
J.K. Sommerfreund ${ }^{\mathrm{a}}$, N. Gandhi ${ }^{\mathrm{b}}$, M.L. Diamond ${ }^{\mathrm{a}, \mathrm{b}, *}, \mathrm{C}$ Mugnai $^{\mathrm{c}}$, M. Frignani ${ }^{\mathrm{c}}$, G. Capodaglio ${ }^{\mathrm{d}}$, \\ M. Gerino ${ }^{\mathrm{e}}$, L.G. Bellucci ${ }^{\mathrm{c}}$, S. Giuliani ${ }^{\mathrm{c}}$ \\ a Department of Chemical Engineering \& Applied Chemistry, University of Toronto, Toronto, ON, Canada \\ ${ }^{\mathrm{b}}$ Department of Geography, University of Toronto, Toronto, ON, Canada

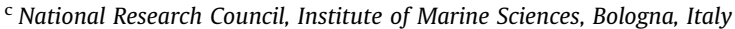 \\ ${ }^{\mathrm{d}}$ Department of Environmental Sciences University of Venice, Venice, Italy \\ e Laboratory of Ecology of Hydrosystems, University of Toulouse, Toulouse, France
}

\section{A R T I C L E I N F O}

\section{Article history:}

Received 17 December 2008

Received in revised form

11 November 2009

Accepted 17 November 2009

Available online 24 December 2009

\section{Keywords:}

Contaminant fate modelling

Venice Lagoon

In-place pollution

Source apportionment

PCBs

OCDD/F

Metals

\begin{abstract}
A B S T R A C T
Contaminant loadings to the Venice Lagoon peaked from 1950s-1980s and although they have since declined, contaminant concentrations remain elevated in sediment and seafood. In order to identify the relative importance of contaminant sources, inter-media exchange and removal pathways, a modified 10-segment fugacity/aquivalence-based model was developed for octachlorodibenzodioxin/furan (OCDD/F), PCB-180, Pb and $\mathrm{Cu}$ in the Venice Lagoon. Results showed that in-place pollution nearby the industrial area, current industrial discharges, and tributary loadings were the main sources of contaminants to the lagoon, with negligible contributions from the atmosphere. The fate of these contaminants was governed by sediment-water exchange with simultaneous advective transport by water circulation. Contaminants circulated amongst the northern and central basins with a small fraction reaching the far southern basin and the Chioggia inlet. As a consequence, we estimated limited contaminant transfer to the Adriatic Sea, trapping the majority of contaminants in the sediment in this "average" circulation scenario which does not account for periodic flooding events.
\end{abstract}

(c) 2009 Elsevier Inc. All rights reserved.

\section{Introduction}

The Venice Lagoon (Fig. 1) is a complex aquatic environment that is under pressure due to numerous competing current and past stresses such as contaminant loadings from industry, human habitation, fish and clam harvesting, and boat traffic. The Lagoon is a $550 \mathrm{~km}^{2}$ transitional water body that receives inflows from 12 major tributaries and exchanges with the Adriatic Sea through 3 inlets that define the north, central and southern basins. Each basin is a network of channels and mud flats with a few principal deep channels ( $>15 \mathrm{~m}$ ) (Umgiesser et al., 2004). The average depth of the lagoon is $1.1 \mathrm{~m}$ with a diurnal tidal variation of $>1 \mathrm{~m}$ (Solidoro et al., 2004b). Riverine to marine gradients from the mainland to the Adriatic Sea are found in water quality (dissolved oxygen, organic matter) and physical parameters (salinity and water residence time) (MAV, 2000; Solidoro et al., 2004a, 2004b).

Contaminant loadings to the Venice Lagoon peaked between the 1950 s and 1980 s during a time of rapid industrialisation

\footnotetext{
* Corresponding author. Fax: +1 4169465992.

E-mail address: miriam.diamond@utoronto.ca (M.L. Diamond).
}

(Frignani et al., 2001, 2005). Although loadings have declined since the 1980 s, likely due to the introduction of legislative controls and improved technologies (Frignani et al., 2001, 2004), present contaminant levels in the lagoon are still of concern due to the elevated concentrations within the industrial canals and the potential health risk posed by consuming clams and fish (Micheletti et al., 2007).

Current contaminant loadings are from direct atmospheric deposition to the lagoon (Gambaro et al., 2004; Guerzoni et al., 2004, 2007), export from watersheds via tributaries (Collavini et al., 2005), and discharges from municipalities and the industrial area of Porto Marghera (Bellucci et al., 2002; Carrer and Leardi, 2006). Porto Marghera, one of the largest industrial areas in Italy, has a petrochemical industry (upon which $70 \%$ of the Italian chemical industry depended), refinery stations, and non-ferrous metal production. Over the last century, these industries have released to the lagoon polychlorinated biphenyls (PCBs), polychlorinated dibenzodioxins and furans (PCDD/Fs), and trace metals (e.g. $\mathrm{Pb}, \mathrm{Cu}$ ) (Carrer and Leardi, 2006). Industries in Porto Marghera discharge to a series of canals that communicate with the central basin of the Lagoon. These discharges have resulted in elevated contaminant concentrations in the sediment of industrial canals and the central basin (Frignani et al., 2005). 


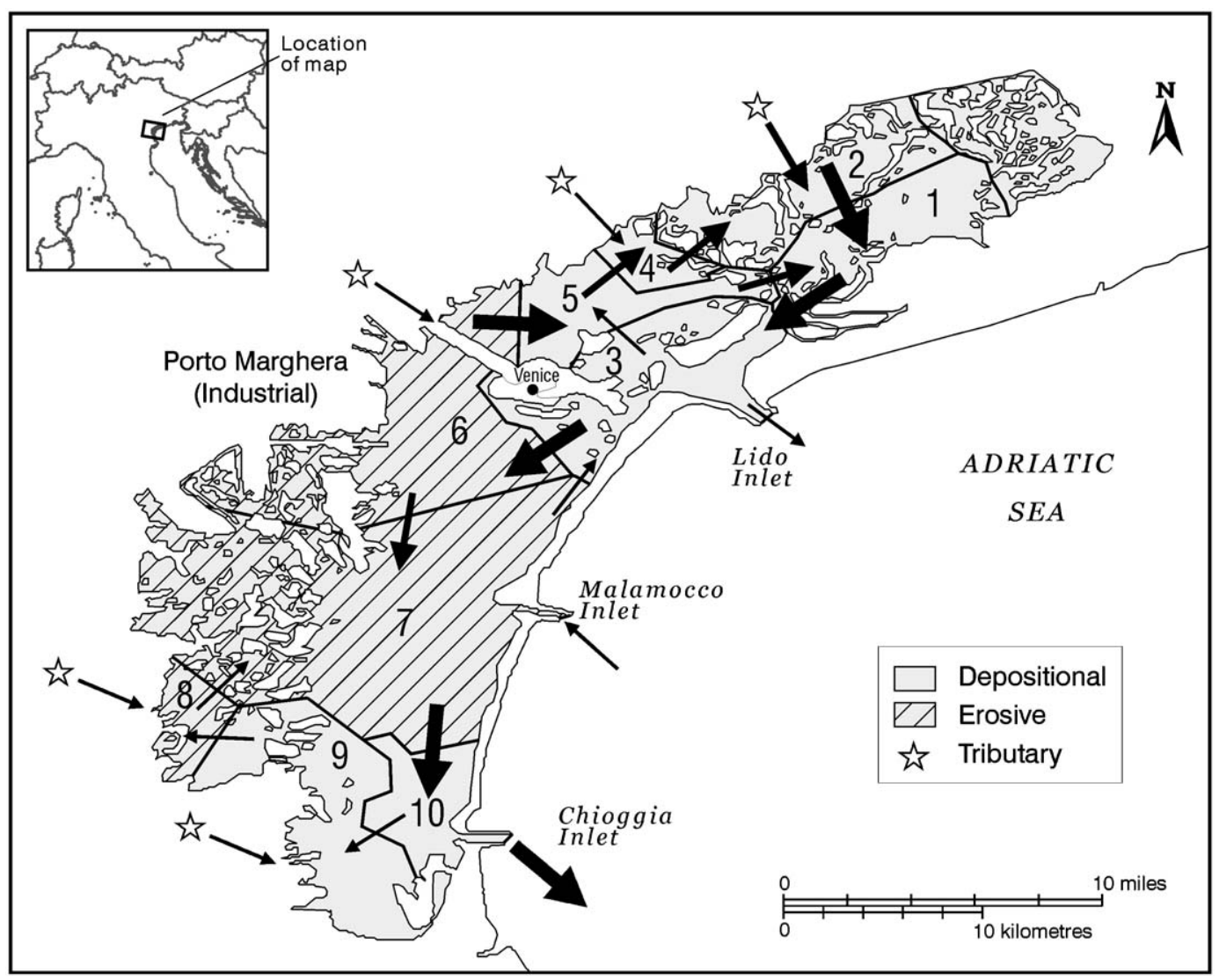

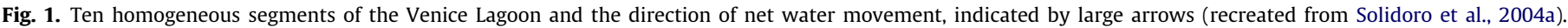

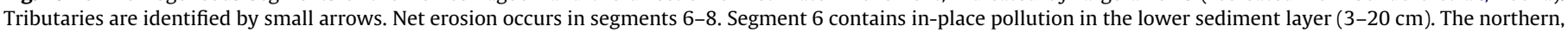
central and southern basins are represented by segments $1-5$, segments $6-8$ and segments 9 and 10 , respectively.

Since the 1990s, particle deposition and resuspension in the Lagoon have increased by an order of magnitude resulting in increased turbidity and an estimated net loss (erosion) of 1.2 million tons per year of sediment from the central basin (Sfriso et al., 2005a). The transformation is largely due to the reduction of macroalgal biomass coverage (Sfriso et al., 2003) and the spread of the introduced Manila clams (Tapes philippinarum Adams and Reeve) which loosen sediment. Manila clams were introduced in 1983 for economic exploitation (Orel et al., 2000). Before 1994, clams were harvested by manual dredges or by divers. Afterwards, harvesting has been done using hydraulic and mechanical dredges that cause sediment reworking down to $30 \mathrm{~cm}$ below the surface. The sediment loss is exacerbated by the reduced supply of sediment from the Lagoon watershed due to the diversion of major rivers from the lagoon that occurred in the past few centuries (Degetto and Cantaluppi, 2004).

The effects of sediment erosion on contaminant distribution and loadings in the Venice Lagoon are unclear. In-place pollution of contaminated sediment (herein referred to as in-place pollution) in the central basin is likely remobilized due to the erosion and resuspension of sediment. Previous models used to evaluate contaminant fate in the Lagoon neglected these effects. For example, Dalla Valle et al. (2003) developed a single-segment fugacity model to evaluate contaminant fate and transport in the central basin of the lagoon while Carrer et al. (2005) developed a hybrid (mechanistic and statistical) model to estimate contaminant concentrations in the water column from measured sediment concentrations. Modelling results of Dalla Valle et al. (2003) consistently underestimated sediment concentrations.

To examine the relative contribution of sources (including inplace pollution of sediment) and to evaluate contaminant fate in light of current particle dynamics, we modified and applied a fugacity/aquivalence-based model (Diamond et al., 1992; Mackay, 2001). We segmented the Lagoon according to modelled hydrodynamic circulation patterns (Solidoro et al., 2004a) and explicitly considered sediment erosion. In addition, for metals we incorporated the loosely coupled TRANsport and SPECiation model (TRANSPEC) (Bhavsar et al., 2004) to account for metal chemistry. Below, we describe the model and its parameterization for the Venice Lagoon. Then we discuss the application of the model to octachlorodibenzodioxin/furan (OCDD/F), PCB-180, $\mathrm{Pb}$ and $\mathrm{Cu}$ to evaluate their sources and fate. These contaminants were selected due to their elevated concentrations in the Lagoon, their toxicity and the availability of loading data.

\section{Materials and methods}

\subsection{Fugacity-aquivalence fate and transport model}

The fugacity-aquivalence approach used in our model has been used to quantify the fate of a variety of contaminants in numerous aquatic system (Diamond, 1995, 1999; Dalla Valle et al., 2003). Details of the model are described elsewhere (Diamond et al., 1992; Mackay, 2001). Fugacity and "aquivalence" (from equivalent aqueous concentration, Mackay and Diamond, 1989) are equilibrium criteria for volatile and non-volatile chemicals (e.g., persistent organic pollutants or POPs and metals), respectively. We used the Level III Quantitative Water Air Sediment Interaction or QWASI model of Mackay et al. (1983) as modified by Diamond (1999), which represents an aquatic environment with three well-mixed homogeneous bulk compartments (water, upper sediment layer and lower sediment layer). Dissolved and particulate phases (e.g., suspended sediment in the water compartment and pore water in the sediment compartment) are in equilibrium within each bulk compartment. The atmosphere is considered to be an infinite source to the system with a constant concentration. 
A mass balance equation is written for each compartment to represent the change in chemical mass with time. All input and removal pathways are assumed to occur simultaneously and instantaneously once a contaminant enters the system. The general mass balance equation for compartment $b$ and chemical $\mathrm{j}$ is:

$V_{b} Z_{b} \frac{d f_{b j}}{d t}=E_{b j}+\sum\left(D_{a b j} f_{a j}\right)-f_{b j} \sum D_{b j}$

where $V_{b}\left(\mathrm{~m}^{3}\right)$ is the volume of compartment $b, f_{a j}$ is the fugacity (Pa) of chemical $j$ in compartment $a, Z$ is the fugacity capacity for organics $\left(\mathrm{mol} \mathrm{m}^{-3} \mathrm{~Pa}^{-1}\right), E_{b j}$ $\left(\mathrm{mol} \mathrm{m}^{-3}\right)$ is the direct emission, $D_{a b j}\left(\mathrm{~mol} \mathrm{~Pa}^{-1} \mathrm{~m}^{-3}\right)$ is the transport rate moving chemical $\mathrm{j}$ from compartment a to $b$, and $D_{b j}$ is the transport rate removing chemical $j$ from compartment $b$. For metals, fugacity is replaced with aquivalence (Mackay and Diamond, 1989) in Eq. (1). Table S1 in the supplementary information lists the D-values included in the model.

Compartment specific versions of Eq. (1) are solved assuming steady-state or pseudo-steady state conditions. The steady-state approximation is used to represent average long-term conditions. The pseudo-steady-state approach, whereby the fugacity of the chemical is specified in a compartment, is used for in-place pollution where sediment concentrations are not at steady state with respect to current loadings, as discussed below (Diamond, 1995).

\subsection{Metals: Speciation-Complexation Module (TRANSPEC)}

Metal distribution between dissolved and particulate phases is sensitive to ambient chemistry, which is system specific. In order to account for metal chemistry and phase, Bhavsar et al. (2004) introduced the TRANsport-SPECiation model or TRANSPEC, where a speciation-complexation model is loosely coupled with the multi-species aquivalence fate and transport model (Diamond et al., 1992). The speciation-complexation model calculates two system- and speciesspecific values of $K_{d} s$ (distribution coefficients): $K_{\mathrm{dCD}}$ (colloidal-to-dissolved phases) and $K_{\mathrm{dPD}}$ (particulate-to-dissolved phases) for total metal and metal species based on ambient aqueous phase chemistry. $K_{d} S$ are used to calculate constituent species' $Z$ values required for the weighted averaged bulk $Z$-values used in the fate and transport model (Diamond et al., 1992).

\subsection{Model application}

The lagoon was segmented into 10 areas according to the analysis of Solidoro et al. (2004a) who used a 2-dimensional finite element hydrodynamic model of the lagoon based on the spatial distribution of physical properties (salinity and water residence time) and other water quality parameters. We chose the circulation patterns and net flow estimates from the reference scenario of "no wind", assuming mean annual tributary flows and an idealised sinusoidal M2 tide levels at inlets that force water circulation. Here, we assume that this scenario reflects the steady-state hydrologic circulation pattern in the lagoon (Fig. 1), although two typical wind regimes, the scirocco from SE and the bora from NE, prevail during fall and winter-spring, respectively. Umgiesser et al. (2004) have evaluated and described the circulation model in detail.

To account for sediment loss in the central basin, two additional transport pathways were included in the QWASI model: (1) a sediment introduction term defined as the addition of sediment from below the lower sediment compartment into the lower sediment layer; and (2) an upward transfer term that moves sediment from the lower to upper sediment layer. Effectively, these parameters are the opposite of the burial pathway. Erosion occurs in segments 6,7 , and 8 (Sfriso et al., 2005a).

\subsection{Model parameterization}

\subsubsection{Fate and transport model}

Physical-chemical properties of contaminants and physical properties of the system are summarised in Tables 1 and 2, respectively. In this reference scenario we assumed average annual meteorological conditions: air and water temperatures of 10 and $13{ }^{\circ} \mathrm{C}$, respectively, and an average rain rate of $2 \mathrm{~mm} /$ day (Frignani and Bellucci, 1999). Dimensions of the water compartments and water circulation flows were taken from Solidoro et al. (2004a). The upper and lower sediment depths were defined as 3 and $20 \mathrm{~cm}$, respectively. The upper sediment layer represents the well-mixed active sediment layer that exchanges with the water column (Gerino et al., 2007).

Fractions of organic carbon in sediment solids for the upper and lower sediment layer were obtained from cores taken by Frignani and Bellucci (1999) and Secco et al. (2005). Values of sediment organic carbon for segments 2, 8 and 9 for which measurements were not available, and hence were estimated using organic carbon distribution maps (MAV, 2000).

Total suspended sediment (TSS) concentrations, the organic carbon fraction of TSS, and DOC in the water column were obtained from bimonthly measurements taken from September 2000 to October 2003 at 27 stations that cover the entire lagoon (MAV, 2006) with the exception of segment 4. We used the geometric means of all measurements to represent the steady-state conditions of the lagoon.
Mass transfer coefficients (MTC, Table 3) were obtained from Mackay (2001). Diffusion between the water column and upper sediment was enhanced by a factor of two to account for bio-irrigation (Wang and Matisoff, 1997; Wijsman et al., 2002). Diffusion of colloidally bound metals was calculated according to the DOC concentration gradient (Bhavsar et al., 2004) with the MTC obtained from Valsaraj et al. (1993, 1996). Pore water DOC measurements were obtained from four sediment cores representing segments 2, 6 and 7. The DOC values for the upper and lower sediment layers were taken as weighted average values of measurements of core sections $0-3$, and 3-5, 5-10, 10-20 cm, respectively (Giani, Personal communication). We assumed the equivalent pore water DOC of segment 6 for segments 3 and 10 . The pore water concentration of DOC in segment 2 was assumed for the remaining segments due to their similar locations on the rivermarine gradient of the Lagoon (Table 3 ).

Sediment deposition, resuspension and burial fluxes $\left(\mathrm{g} \mathrm{m}^{-2} \mathrm{~d}^{-1}\right)$ were calculated from: (1) sedimentation rates derived from data from 16 sediment traps deployed from 1997-1999 and 2001-2002, representing all segments except 2, 8 and 9 (Sfriso et al., 2005b); (2) burial rates based on the geometric mean obtained from ${ }^{210} \mathrm{~Pb}$ estimates in all non-erosive segments (Frignani and Bellucci, 1999; Frignani et al., 2001, 2005), and (3) an erosion rate estimated using the sediment loss estimate of $1.43 \mathrm{~cm} \mathrm{y}^{-1}$ (Sfriso et al., 2005a).

A particle mass balance was constructed for the upper and lower sediment compartment for each segment. Particle mass was assumed to be at steady state. In non-erosive or net depositional segments $(1-5,9,10)$, the upper sediment particles deposit from the water column and mix with the lower sediment. Sediment is lost by resupension to the water column, and mixing and burial to the lower sediment. There is no net exchange of sediment between layers as a result of mixing, but there is net movement downwards as a result of burial. Resuspension was then calculated as the difference between sediment trap flux and burial. Erosive segments were parameterized similarly however burial was replaced by a net upward movement of sediment particles (sediment introduction) and deposition was calculated as the difference between the sediment trap flux and sediment introduction due to erosion. Note that the particle balance neglects particle degradation, which we justified based on the low organic content of sediment particles. Calculated resuspension rates were consistent with the average of the estimated resuspension rates from two stations in the erosive central basin (Bellucci et al., 2007).

\subsubsection{Speciation-complexation model}

The Windermere Humic-Aqueous Model (Tipping, 1998) was selected to estimate water column speciation, due to its ability to represent the binding of metals to organic matter (Bhavsar et al., 2008). However, because WHAM does not adequately treat redox conditions and the requisite sediment pore water chemistry data were not available, literature $K_{d}$ values (both $\log K_{\mathrm{dCD}}$ and $\log K_{\mathrm{dPD}}$ equal to $5.1 \mathrm{~L} \mathrm{~kg}^{-1}$ for $\mathrm{Pb}$; $\log K_{\mathrm{dCD}}$ equal to $5.5 \mathrm{~L} \mathrm{~kg}^{-1}$ and $\log K_{\mathrm{dPD}}$ equal to $4.2 \mathrm{~L} \mathrm{~kg}^{-1}$ for $\mathrm{Cu}$ ) were used for the upper and lower sediment layers (USEPA, 2005).

The major soluble forms considered in the WHAM module were: $\mathrm{Me}^{2+}$ $\mathrm{MeOH}^{+}, \mathrm{Me}(\mathrm{OH})_{2}, \mathrm{Me}(\mathrm{OH})_{3}^{-}, \mathrm{MeSO}_{4}, \mathrm{MeCl}^{+}, \mathrm{MeCl}_{2}, \mathrm{MeCO}_{3}, \mathrm{Me}\left(\mathrm{CO}_{3}\right)_{2}^{-2}$. In the absence of measured values, the major ionic component $\left(\mathrm{Na}^{+}, \mathrm{Mg}^{2+}, \mathrm{Ca}^{2+}, \mathrm{Cu}^{2+}\right.$ $\mathrm{Cl}^{-}, \mathrm{SO}_{4}^{2-}$ and $\mathrm{F}^{-}$) molar concentrations were calculated from salinity measurements taken in 1992 at 12 stations from segments 2, 3 and 6 representing fresh marine and mixed water, respectively (Giani, Personal communication). For three stations, salinity measurements were made during a complete tidal cycle. Geometric means of measured salinity were assigned to the remaining segments identified as fresh or marine water. We considered particulate-phase metal complexation with organic matter and $\mathrm{Al}$ and Fe oxides fractions. Complexation with manganese oxides was not considered due to the lack of data. Since the concentrations of suspended particulate-phase $\mathrm{Al}$ and $\mathrm{Fe}$ oxides were not available, values from the upper sediment fractions were used (Frignani et al. 1999). Particulate-phase and dissolved organic matter (POM and DOM, respectively) were assumed to consist of $15 \%$ humic and $85 \%$ fulvic acids in all segments. Default WHAM binding constants were used for POM and DOM complexation.

\subsubsection{Contaminant loading estimates}

Below we discuss each source of contaminant loadings (Fig. 3, Table S2) with the exception of emissions from the City of Venice and boat and shipping for which estimates were not available. We were not able to assess the uncertainty of loading estimates.

- Tributary loadings of total (dissolved and particulate-phase) Pb, Cu, PCB-180 and OCDD/F were estimated by Collavini et al. (2005) from measured concentrations of dissolved and particulate phases of these contaminants at major outlets in 1999. The 11 tributaries analysed for $\mathrm{Pb}, \mathrm{Cu}$ and PCB-180 represent $90 \%$ of the lagoon catchment surface area with a mean total discharge of $34.5 \mathrm{~m}^{3} \mathrm{~s}^{-1}$. The four tributaries measured for OCDD/F represent $42 \%$ of the drainage basin. We assumed the equivalent concentration for the remaining unmeasured tributaries.

- Industrial inputs were calculated using the Water Authority of Venice (MAV) and Pollution Prevention Service (SAMA) data (MAV-SAMA, 2004; Ferrari, 
Table 1

Physical-chemical properties of organic contaminants, determined at $25^{\circ} \mathrm{C}$; half-lives in sediment and water are referred to an annual average temperature of $7{ }^{\circ} \mathrm{C}$.

\begin{tabular}{|c|c|c|c|c|c|c|c|}
\hline Chemical Name & $\begin{array}{l}\text { Molecular Weight } \\
\left(\mathrm{g} \mathrm{mol}^{-1}\right)\end{array}$ & $\begin{array}{l}\text { Melting Point } \\
\left({ }^{\circ} \mathrm{C}\right)\end{array}$ & Log Коa & $\begin{array}{l}\text { HLC } \\
\left(\mathrm{Pa} \mathrm{m}^{3} \mathrm{~mol}^{-1}\right)\end{array}$ & Log Kow & $\begin{array}{l}\text { Half-life Water }{ }^{\text {a }} \\
\text { (h) }\end{array}$ & $\begin{array}{l}\text { Half-life Sediment } \\
\text { (h) }\end{array}$ \\
\hline OCDD & $460^{\mathrm{b}, \mathrm{c}}$ & $322^{\mathrm{b}, \mathrm{c}}$ & $13^{d}$ & $0.68^{b, c}$ & $8.2^{\mathrm{b}, \mathrm{c}}$ & 79,000 & 1300,000 \\
\hline OCDF & $443.8^{\mathrm{b}}$ & $258^{\mathrm{b}, \mathrm{c}}$ & $12.84^{\mathrm{d}}$ & $0.19^{\mathrm{b}, \mathrm{c}}$ & $8^{\mathrm{b}, \mathrm{c}}$ & 192,000 & 250,000 \\
\hline РСВ 180 & $395.3^{b}$ & $113.9^{b}$ & $10.17^{\mathrm{e}}$ & $7.77^{e}$ & $7.66^{\mathrm{e}}$ & 240,000 & 330,000 \\
\hline
\end{tabular}

Koa and Kow are the octanol-air and octanol-water partition coefficients, respectively; HLC is the Henry Law constant.

a Sinkkonen and Paasivirta (2000).

b Mackay et al. (1992).

c Shiu and Ma (2000).

${ }^{\mathrm{d}}$ Harner et al. (2000).

e Schenker et al. (2005).

Table 2

Segment dimensions defined by Solidoro et al. (2004a) and parameter values used for the Venice Lagoon model.

\begin{tabular}{|c|c|c|c|c|c|c|c|c|c|c|}
\hline $\begin{array}{l}\text { Segment Location } \\
\text { Segment } \#^{\mathrm{a}}\end{array}$ & $\begin{array}{l}\text { NBnE } \\
1\end{array}$ & $\begin{array}{l}\text { NBnW } \\
2\end{array}$ & $\begin{array}{l}\text { NBcW } \\
3\end{array}$ & $\begin{array}{l}\text { NBcC } \\
4\end{array}$ & $\begin{array}{l}\text { NBcE } \\
5\end{array}$ & $\begin{array}{l}\text { CBW } \\
6\end{array}$ & $\begin{array}{l}\text { CBE } \\
7\end{array}$ & $\begin{array}{l}\text { SBW } \\
8\end{array}$ & $\begin{array}{l}\text { SBC } \\
9\end{array}$ & $\begin{array}{l}\text { SBE } \\
10\end{array}$ \\
\hline Water Depth (m) $)^{a}$ & 1.3 & 0.8 & 3.4 & 0.5 & 1.0 & 1.6 & 2.4 & 0.9 & 0.7 & 1.7 \\
\hline Area $\left(\mathrm{km}^{2}\right)^{\mathrm{a}}$ & 43.5 & 35.3 & 31.3 & 11.5 & 22.2 & 54.3 & 89.4 & 31.7 & 29.5 & 40.6 \\
\hline Organic Carbon $(g / g)$ Suspended Sediment ${ }^{b}$ & 0.02 & 0.02 & 0.01 & 0.01 & 0.01 & 0.03 & 0.02 & 0.03 & 0.02 & 0.01 \\
\hline Organic Carbon (g/g) Upper Sediment & $0.02^{\mathrm{e}}$ & $0.02^{\mathrm{c}}$ & $0.01^{\mathrm{d}}$ & $0.01^{\mathrm{c}}$ & $0.01^{\mathrm{d}}$ & $0.01^{\mathrm{c}}$ & $0.02^{\mathrm{c}}$ & $0.03^{\mathrm{e}}$ & $0.02^{\mathrm{e}}$ & $0.01^{\mathrm{c}}$ \\
\hline Organic Carbon $(\mathrm{g} / \mathrm{g})$ Lower Sediment & $0.01^{\mathrm{e}}$ & $0.01^{\mathrm{c}}$ & $0.01^{\mathrm{d}}$ & $0.01^{\mathrm{c}}$ & $0.01^{\mathrm{d}}$ & $0.01^{\mathrm{c}}$ & $0.02^{\mathrm{c}}$ & $0.03^{\mathrm{e}}$ & $0.02^{\mathrm{e}}$ & $0.01^{\mathrm{c}}$ \\
\hline Total Suspended Solids $\left(\mathrm{g} / \mathrm{m}^{3}\right)^{\mathrm{b}}$ & 15.9 & 15.4 & 14.1 & 22.5 & 22.5 & 22.2 & 11.3 & 17.0 & 16.2 & 10.4 \\
\hline Dissolved Organic Carbon $(\mathbf{m g} / \mathbf{L})^{\mathrm{b}}$ & 2.6 & 2.4 & 2.4 & 2.3 & 2.3 & 2.1 & 2.0 & 3.3 & 3.2 & 2.1 \\
\hline Upper Sediment Pore Water - Dissolved Organic Carbon $(\mathbf{m g} / \mathbf{L})^{1}$ & 11.8 & 11.8 & 14.0 & 11.8 & 11.8 & 14.0 & 4.9 & 11.8 & 11.8 & 14.0 \\
\hline Lower Sediment Pore Water - Dissolved Organic Carbon $(\mathbf{m g} / \mathbf{L})^{1}$ & 1.4 & 1.4 & 1.8 & 1.4 & 1.4 & 1.8 & 1.9 & 1.4 & 1.4 & 1.8 \\
\hline Solid Volume Fraction Upper Sediment & $0.5^{\mathrm{f}}$ & $0.5^{\mathrm{c}}$ & $0.6^{\mathrm{f}}$ & $0.5^{\mathrm{c}}$ & $0.6^{\mathrm{f}}$ & $0.6^{\mathrm{c}}$ & $0.6^{c}$ & $0.6^{\mathrm{f}}$ & $0.6^{\mathrm{f}}$ & $0.7^{\mathrm{c}}$ \\
\hline Solid Volume Fraction Lower Sediment & $0.6^{\mathrm{f}}$ & $0.6^{\mathrm{c}}$ & $0.7^{\mathrm{f}}$ & $0.6^{\mathrm{c}}$ & $0.6^{\mathrm{f}}$ & $0.6^{\mathrm{c}}$ & $0.6^{\mathrm{c}}$ & $0.6^{\mathrm{f}}$ & $0.7^{\mathrm{f}}$ & $0.7^{\mathrm{c}}$ \\
\hline Aluminium oxide \% - upper sediment ${ }^{\mathrm{c}}$ & 10.2 & 10.2 & 10.4 & 10.2 & 10.2 & 10.4 & 10.0 & 10.2 & 10.2 & 10.4 \\
\hline Iron oxide \% - upper sediment ${ }^{\mathrm{c}}$ & 3.4 & 3.4 & 3.5 & 3.4 & 3.4 & 3.5 & 3.5 & 3.4 & 3.4 & 3.5 \\
\hline Deposition $\left(g / \mathbf{m}^{2} \mathbf{d}\right)$ & $73^{h}$ & $73^{i}$ & $469^{\mathrm{h}}$ & $251^{\mathrm{h}}$ & $609^{h}$ & $354^{\mathrm{h}}$ & $45^{\mathrm{h}}$ & $45^{\mathrm{i}}$ & $375^{\mathrm{i}}$ & $375^{\mathrm{h}}$ \\
\hline Resuspension $\left(g / \mathrm{m}^{2} \mathbf{d}\right)^{\mathrm{g}}$ & 69 & 69 & 465 & 247 & 605 & 364 & 56 & 56 & 371 & 371 \\
\hline Sediment Mixing $\left(g / \mathbf{m}^{2} \mathbf{d}\right)^{\mathrm{j}}$ & 0.22 & 0.22 & 0.22 & 0.22 & 0.22 & 0.22 & 0.22 & 0.22 & 0.22 & 0.22 \\
\hline Burial $\left(g / \mathbf{m}^{2} \mathbf{d}\right)^{\mathrm{c}}$ & 3.7 & 3.7 & 3.7 & 3.7 & 3.7 & NA & NA & NA & 3.7 & 3.7 \\
\hline Sediment Introduction $\left(\mathrm{g} / \mathrm{m}^{2} \mathrm{~d}\right)^{\mathrm{k}}$ & NA & NA & NA & NA & NA & NA & 10.7 & 10.7 & NA & NA \\
\hline Upward Transfer $\left(g / m^{2} d\right)^{k}$ & NA & NA & NA & NA & NA & 10.7 & 10.7 & 10.7 & NA & NA \\
\hline
\end{tabular}

NA-Not Applicable

NB — North Basin, CB —Central Basin, SB —-South Basin, C—central, N—northern, W—west, E-east

a Solidoro et al. (2004a)

b MAV (2006) - segment 5 values were assigned to segment 4

c Frignani et al., 1999.

d Secco et al. (2005)

e MAV (1999) as qualitative guide

f Amos et al. (2004)

g same as deposition data

h Sfriso et al. (2005a)

${ }^{\mathrm{i}}$ Degetto and Cantaluppi (2004) as a guide for similarities to assign values

j Sfriso et al. (2005b)

${ }^{k}$ Assumed same rate as Bhavsar et al. (2004)

${ }^{1}$ Unpublished data, M. Giani (personal communication).

Table 3

Mass transfer coefficients (MTC) used in the model.

\begin{tabular}{|c|c|c|c|}
\hline MTC & Organic Dissolved $^{\mathbf{a}}\left(\mathrm{m} \mathrm{h}^{-1}\right)$ & Metal Dissolved ${ }^{\mathbf{b}}\left(\mathrm{m} \mathrm{h}^{-1}\right)$ & Metal Colloidal $^{\mathbf{c}}\left(\mathrm{m} \mathrm{h}^{-1}\right)$ \\
\hline Water side $\left(k_{\mathrm{ww}}\right)$ & $3 \times 10^{-2}$ & NA & NA \\
\hline Air side over water $\left(k_{\mathrm{aw}}\right)$ & 3 & NA & NA \\
\hline Water side over sediment $\left(k_{\mathrm{ws}}\right)$ & $10^{-2}$ & $10^{-5}$ & $7 \times 10^{-7}$ \\
\hline Sediment side $\left(k_{\mathrm{ss}}\right)$ & $10^{-4}$ & $10^{-6}$ & $10^{-8}$ \\
\hline
\end{tabular}

a Mackay (2001)

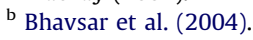

${ }^{\mathrm{c}}$ Valsaraj et al. (1991, 1996).

Personal communication), which account for effluents from the Porto Marghera petrochemical plant, the oil refinery, thermal power stations, chemical plants and the main water treatment plant in the lagoon. These are based on in situ measurements of the difference between water concentrations entering and exiting each facility during 2001, with the exception of OCDF for which we used values from 2002. The emissions enter a series of canals that eventually discharge into segment 6 . An unknown fraction of the industrial discharges is retained in the sediment of the canals. To add to the uncertainty, the canal sediments also contain contaminants as a legacy of past emissions. As a first estimate, we assumed $100 \%$ of current 
industrial loadings enter segment 6. This assumption is evaluated below.

- Bulk atmospheric deposition of PCB-180 and OCDD/F (wet and dry deposition of gas and particulate phases) was estimated as the geometric mean of gas-phase concentrations measured at two locations in segments 3 and 6 every 15 days from March 2002 to June 2003 when winds exceeded $1 \mathrm{~m} \mathrm{~s}^{-1}$ (Gambaro et al., 2004; Manodori, 2006). We assumed a dry deposition velocity of $0.003 \mathrm{~m} \mathrm{~s}^{-1}$, an aerosol density of $1500 \mathrm{~kg} \mathrm{~m}^{-3}$, and total suspended particle concentration (TSP) of $20 \mu \mathrm{g} \mathrm{m}^{-3}$ (Mackay et al., 2001). A scavenging ratio of 200,000 (Mackay et al., 2001) was considered to account for wet deposition. Wet and dry particle deposition of $\mathrm{Pb}$ and $\mathrm{Cu}$ was calculated from measured $\mathrm{PM}_{10}$ concentrations and thus may have underestimated total deposition (G. Capodaglio, personal communication). Atmospheric stack emissions were not explicitly included.

- Reintroduction of in-place pollution from segment 6 was evaluated as follows. The lower sediment layer of segment 6 has elevated contaminant concentrations from historic inputs. Due to sediment erosion, contaminants are reintroduced into the system. This process is modelled as sediment introduction from the lower to upper sediment. To estimate this loading, a pseudosteady-state formulation (Diamond, 1995) was used whereby the fugacity/ aquivalence of the lower sediment layer of segment 6 was specified for each contaminant based on measured concentrations, rather than solved for in the mass balance equations. Thus, contaminant in the lower sediment layer is considered as an infinite source, similarly to emissions from air. Those concentrations were calculated from geometric means of the measured lower sediment concentrations determined in three sediment cores (cores E, E1 and E14), segmented by depth at every $2 \mathrm{~cm}$ to a maximum depth of $20 \mathrm{~cm}$, (Frignani and Bellucci, 1999; Frignani et al., 2001, 2004). The two "hot" spots (highest chemical concentrations that were located close to the industrial area and the city of Venice) (Frignani et al., 2001, 2004) were excluded from the calculation because they biased high the mean for the entire segment.

A steady-state version of the model was used to estimate "long term average" conditions in the Lagoon assuming constant external and in-place loadings. Eq. (1) was solved simultaneously for the fugacity-aquivalence of each compartment (except for the lower sediment layer of segment 6) in each segment (29 equations). Parameter values were not calibrated to maximise the correspondence between measured and modelled concentrations, but their associated uncertainty is discussed by Sommerfreund et al. (2009). The model was written in Visual Basic and runs on a PC in a Windows ${ }^{\odot}$ environment.

\section{Model outcomes}

\subsection{Comparison with measured data}

We evaluated the model by comparing measured and modelled concentrations for soluble (dissolved and colloidal phases) $\mathrm{Pb}$ and $\mathrm{Cu}$ in the water column and all contaminant concentrations in the upper sediment. Measured water concentrations were not available for PCB-180 and OCDD/F. The measured soluble $\mathrm{Pb}$ and $\mathrm{Cu}$ concentrations were $3 \mathrm{y}$ averages of monthly samples at 27 stations representing all segments except segment 4 (MAV, 2006). For Pb, Cu, OCDD/F and PCB-180, sediment concentrations were obtained from one vertically segmented core in each of segments 2, 4, and 10 (Frignani et al., 1999; Lucchini et al., 2001/2002). For segment 6, sediment concentrations from five cores were obtained for OCDD/F and PCB-180 (Frignani et al., 1999, 2001, 2004, 2005) and 21 cores for $\mathrm{Pb}$ and $\mathrm{Cu}$ (Frignani et al., 1999; Lucchini et al., 2001/2002). In addition, concentrations of $\mathrm{Pb}, \mathrm{Cu}$ and $\mathrm{PCB}-180$ were available from one core that was sampled in segment 7 (Frignani et al., 1999; Lucchini et al., 2001/2002). The measured sediment concentrations do not necessarily capture the spatial variability nor necessarily reflect the average concentration in all segments.

Measured and modelled concentrations of all contaminants in water and sediment were within an order-of-magnitude of each other. The largest discrepancies were for sediment concentrations of segments 7 and 10 where modelled exceeded measured concentrations by 2-6 times. Soluble phase $\mathrm{Pb}$ concentrations were consistently overestimated by the model. In addition, modelled exceeded measured sediment concentrations of PCB-

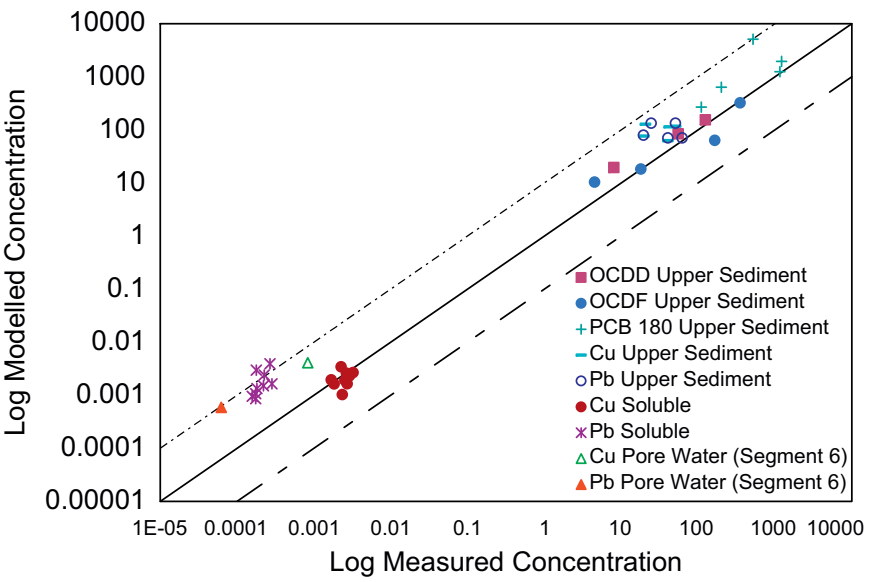

Fig. 2. A comparison of modelled and measured concentrations (where available) for upper sediments (all contaminants; $\mathrm{ng} \mathrm{kg}^{-1}$ or $\mathrm{g} \mathrm{m}^{-3}$ ), soluble water concentrations (dissolved and colloidal fractions of $\mathrm{Cu}$ and $\mathrm{Pb} ; \mathrm{g} \mathrm{m}^{-3}$ ) and pore water concentration (segment $6 ; \mathrm{Pb}$ and $\mathrm{Cu} ; \mathrm{g} \mathrm{m}^{-3}$ ). The solid line represents modelled $=$ measured, the hatched lines represent \pm an order of magnitude .

180 by $1.3-9$ times with the greatest overestimate in segment 6 (Fig. 2).

The overestimated sediment concentrations of segments 7 and 10 are consistent with exclusion from the model parameterization of contaminant removal during episodic flooding events in the lagoon. The discrepancy of $\mathrm{Pb}$ in the soluble phase is likely driven by the overestimate of colloidal-bound $\mathrm{Pb}$ within the soluble phase as calculated by WHAM (Bhavsar et al., 2008).

Atmospheric deposition fluxes calculated from atmospheric loading for OCDD, OCDF and PCB-180 (0.274, 0.018 and $180 \mathrm{pg}$ $\mathrm{m}^{-2} \mathrm{~d}^{-1}$, respectively) were about an order of magnitude lower than those available for total PCDD/F and total PCB (Rossini et al., 2005; Guerzoni et al., 2007) and those calculated for PCB-180 by Manodori et al., 2007). PCB-180 concentrations may be overestimated due to overestimated loadings and our neglect of flooding events. Of all contributions, industrial loadings of PCB180 and other contaminants are probably most uncertain given the uncertainty in our understanding of whether the industrial canals act as a source or sink. Maximum PCB sediment concentrations are 80-1583 times higher in the industrial canals than in the lagoon (Frignani et al., 2004). Furthermore, the major industrial source of PCBs is located in the oldest part of the industrial area, suggesting that significant chemical is deposited in the canal before reaching the lagoon (Carrer and Leardi, 2006).

To evaluate the reliability of the loadings of PCB-180, several industrial loading scenarios were analysed. The fraction of industrial emissions retained by the sediment of the industrial canals was estimated by running the model with export fractions varying from 0 to 1 , while keeping all other loadings constant. The best fit with measured values corresponded to $10-20 \%$ industrial emissions (in particular for segments 6 and 10, whereas for segment 7 the best fit corresponded to $90 \%$ industrial emission) suggesting that the transfer of PCB-180 as well as other contaminants from the canals to the lagoon might be overestimated in the model (Fig. 3a).

Using the $100 \%$ industrial loading scenario (i.e. no retention in the industrial canals), in-place pollution mobilised by anthropogenically induced sediment erosion contributed significantly to all contaminant burdens, (i.e. $29-52 \%$ of total OCDD/F, $\mathrm{Cu}$ and $\mathrm{Pb}$ loadings) with the exception of PCB-180 (5\%) (Fig. 3b). Present industrial sources accounted for $20-64 \%$ of loadings for OCDD/F, PCB-180 and $\mathrm{Pb}$ and only 9\% of $\mathrm{Cu}$ loadings. Non-industrial sources contribute significantly to the loadings of OCDD, $\mathrm{Cu}$ and, 

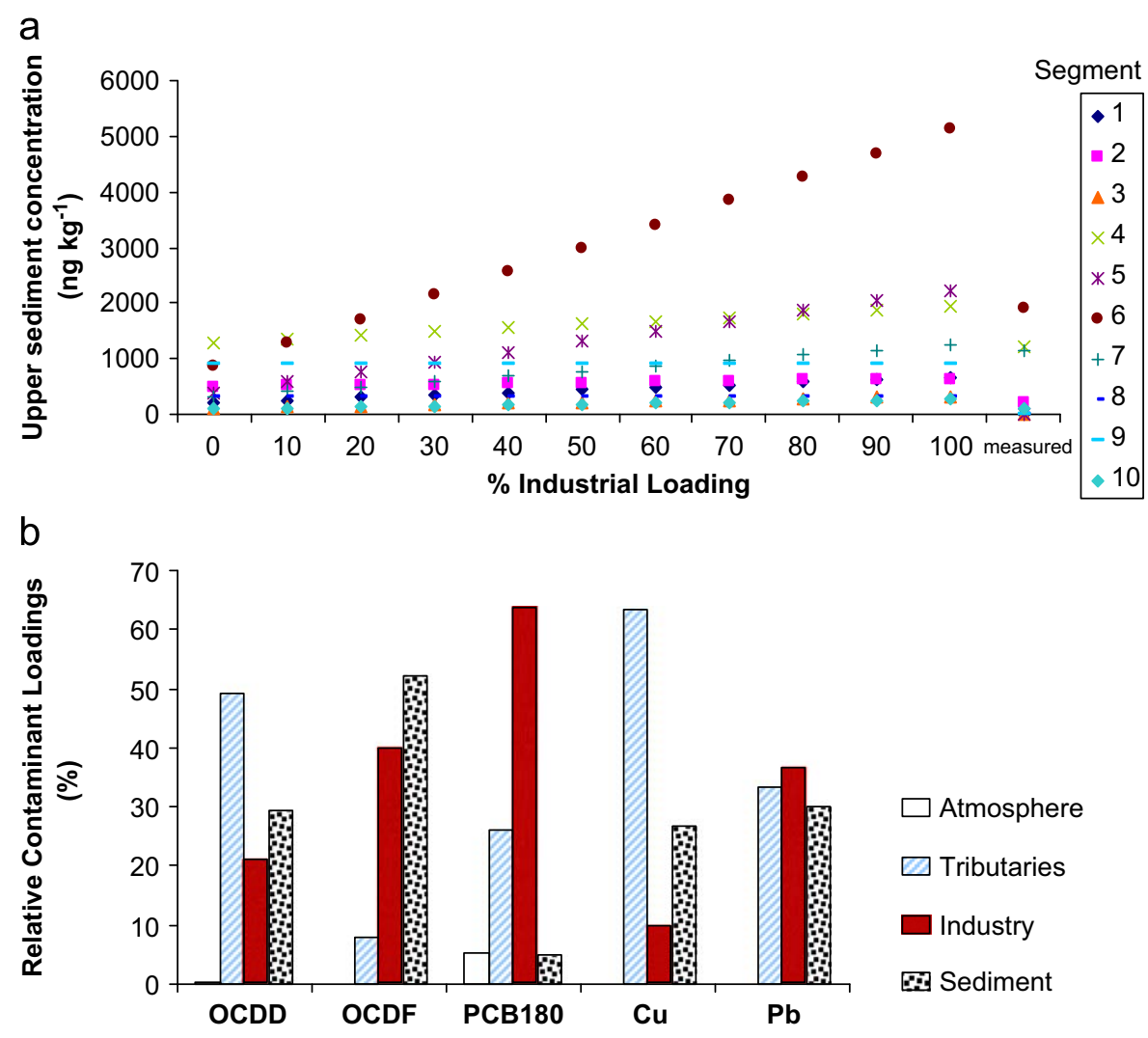

C

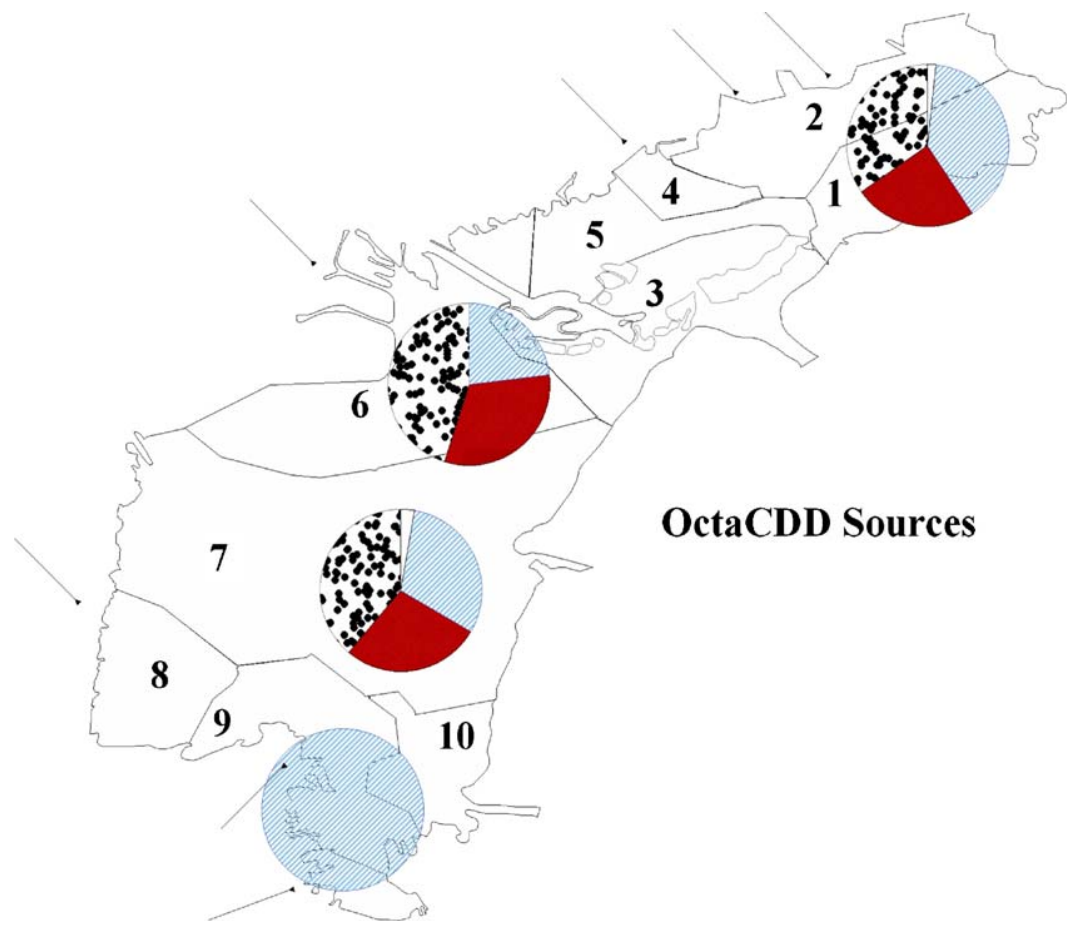

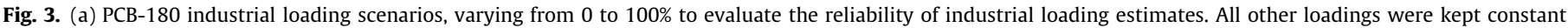

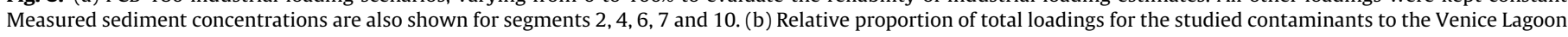

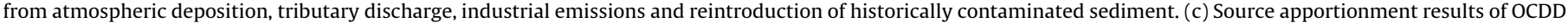
for segments $1,6,7$, and 9 as illustrative of the northern, central and southern basin, respectively.

$\mathrm{Pb}$. For example, tributaries contributed most $\mathrm{Cu}$ and OCDD loadings (Fig. 3b). However, if the fraction retained by the industrial canal sediments is higher, as suggested by the PCB180 scenarios and sediment studies (Frignani et al., 2004), then the relative importance of current industrial sources would decrease. For example, when we optimised loadings for PCB-180 (as discussed above), the tributaries became its dominant source, followed by industry, atmospheric deposition and in-place pollution. We acknowledge that this analysis neglects nonquantified sources (e.g. city of Venice, boating and shipping) that 
could be significant. The large contribution of in-place pollution is likely driven by the large size of segment 6 . In our approach the same concentration and magnitude of erosion was used throughout segment 6 although variability in both terms is probable.

\subsection{Source apportionment}

To evaluate the contribution of each of the above described sources to each segment we used a source apportionment analysis. Model scenarios were run with one source at a time to elucidate the contribution of contaminant sources to the geographic segments. This approach employs the linear additivity principle whereby contaminant concentrations (and mass) from individual sources linearly add to the total because of the linearity of the model (Stiver and Mackay, 1989; Diamond, 1995). Although the absolute contributions from each source are uncertain, the qualitative results are instructive.

The source apportionment analysis reflected the location of loading sources and the dominant hydrologic circulation pattern of the Lagoon. Fifty to $94 \%$ of total OCDD/F, PCB180, Cu and $\mathrm{Pb}$ loadings enter the Lagoon through segment 6 in the central basin from industry and in-place pollution, followed by a significant contribution from tributaries (Collavini et al., 2005). These loads circulate to the northern lagoon (within segments 5, 4, 2, 1 and 3), with limited transport to the far southern lagoon (segments 8 and 9). For example, $60 \%$ of total OCDD loadings to segment 1 in the far northern lagoon were from in-place pollution and present industrial sources originating from segment 6 whereas nearly $100 \%$ of loadings in segment 9 in the far southern lagoon were from tributaries (Fig. 3c). The relative importance of non-industrial sources of OCDD, notably tributaries, was $40-80 \%$ greater far from the central lagoon (25\%) which is consistent with the results of Micheletti et al. (2007). Thus, the dominant sources of $\mathrm{OCDD} / \mathrm{F}, \mathrm{Pb}$ and $\mathrm{Cu}$ in the northern lagoon, with the exception of areas adjacent to tributaries (segment 2), were estimated to be in-place pollution and current industrial loadings. For PCB-180, industrial emissions were the main source for nearby segments 5 and 6 only.

Contaminant circulation follows the pattern of water circulation. Extensive water exchange occurs amongst the northern and central basins (netflows range from 5 to $70 \mathrm{~m}^{3} \mathrm{~s}^{-1}$ ). Approximately $70 \%$ of water leaving segment 6 reaches the northern basin while only $30 \%$ flows southward (Solidoro et al., 2004a). Once the water reaches the southern lagoon (segment 10), 94\% is exported to the Adriatic Sea through the Chioggia inlet while the remaining $6 \%$ is transferred to the far southern lagoon (segment 9). Thus, it is not surprising that the contaminant loadings in the southern lagoon are dominated by local tributaries and not sources originating in the central and northern basins. Segment-tosegment transfer of contaminants is mediated by in-segment processes, as discussed below.

\subsection{Contaminant fate}

Despite $\sim 75 \%$ of $\mathrm{Pb}$ and $\mathrm{Cu}$ being in the soluble form (dissolved + colloidal phases), their fate, similar to that of OCDD/ $\mathrm{F}$ and PCB-180, was mediated by particle dynamics of sediment deposition and resuspension with minimal importance of sediment-water diffusion (Fig. 4). This was expected in a shallow energetic system such as the Venice Lagoon (Diamond, 1995). As
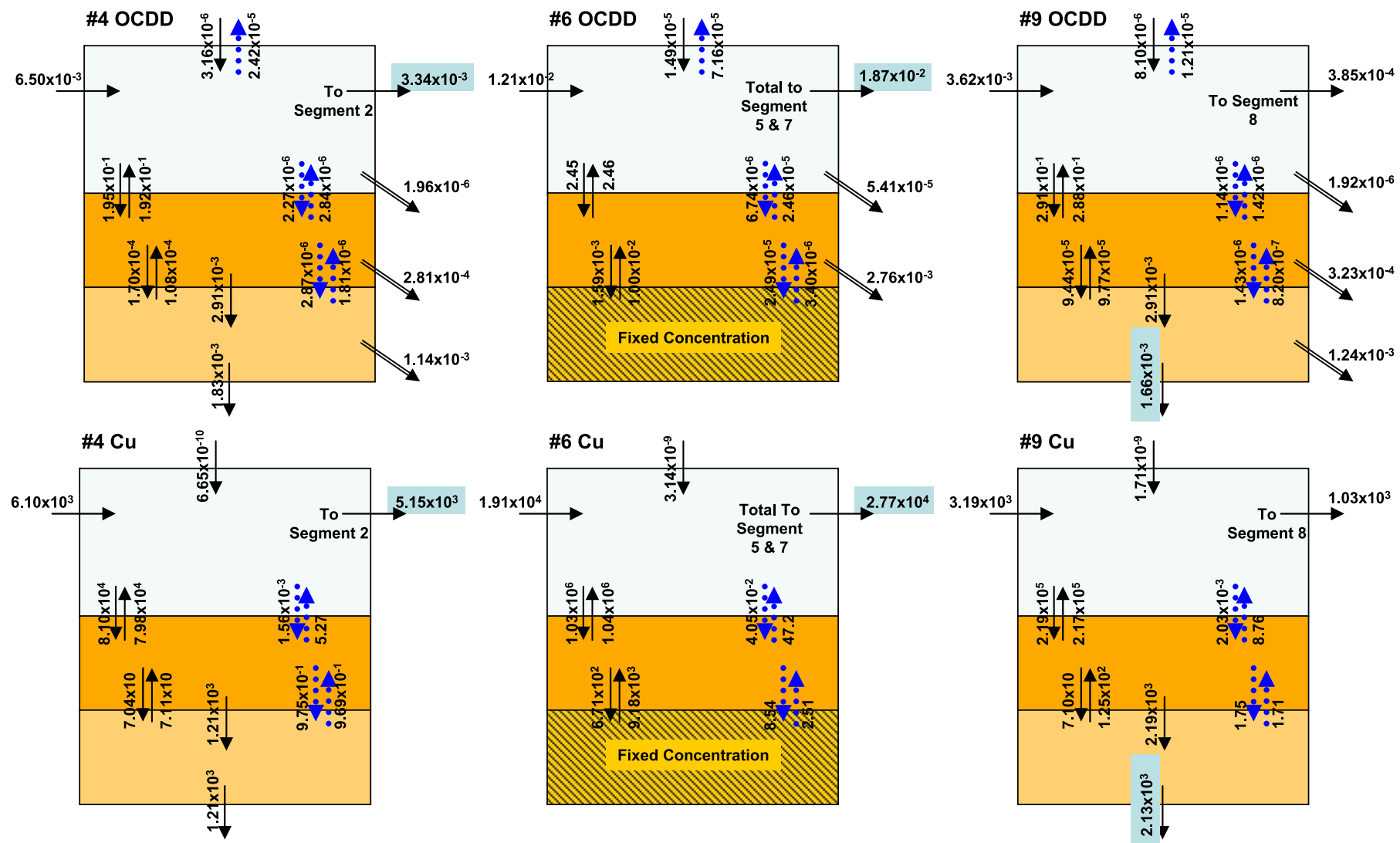

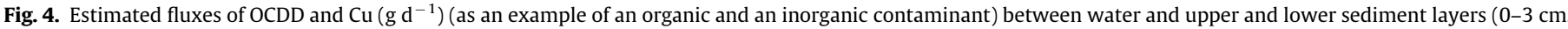

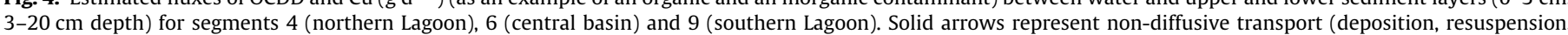

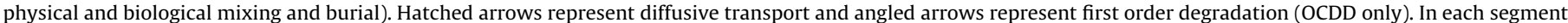
the dominant removal pathway is highlighted. 
noted above, sediment resuspension has been increased due to the introduction of Manila Clams and clam harvesting (Sfriso et al., 2005b). The magnitude of gross contaminant flux between water and upper sediment was 10-1000 times greater than the net contaminant deposition (i.e bulk deposition minus resuspension) $\left(1.9 \times 10^{-4}\right.$ to $0.35 \mathrm{~g} \mathrm{~d}^{-1}$ of PCB-180 and $\mathrm{OCDD} / \mathrm{F}$; $0.81-7.12 \times 10^{3} \mathrm{~g} \mathrm{~d}^{-1}$ of $\mathrm{Pb}$ and $\mathrm{Cu}$ ), with the exception of the area of in-place pollution (segment 6 ). Consistent with the modelling results of Dalla Valle et al. (2003), net contaminant loss from the upper sediment via resuspension occurred in segment 6, allowing for the export of contaminants from this area. Ultimately, contaminant was lost through lower sediment burial in non-erosive segments, varying from $1.12 \times 10^{-4}$ to $4.26 \times 10^{-2} \mathrm{~g} \mathrm{~d}^{-1}$ for PCB-180 and $\mathrm{OCDD} / \mathrm{F}$, and $1.21 \times 10^{3}$ to $7.1 \times 10^{3} \mathrm{~g} \mathrm{~d}^{-1}$ for $\mathrm{Pb}$ and $\mathrm{Cu}$ (Fig. 4).

Water circulation (outflow) is the dominant contaminant removal pathway from segments 1 to 7 in the northern and central basin (22-79\% for OCDD/F and PCB-180; 56-98\% for Cu and $\mathrm{Pb}$, respectively). In contrast, removal from the southern basin segments $(9,10)$ was dominated by burial $(12-70 \%$ removal for all contaminants) further limiting transfer from the central lagoon to the far southern lagoon through segment 10 and to the Adriatic Sea (Fig. 4) under this "no wind" scenario.

Model results suggest that the fate of PCB-180 and OCDD/F in the northern and central basins could be influenced by insegment loss via degradation and volatilisation (the latter was only appreciable for PCB-180) (Fig. 4). Since the degradation half lives used (suggested for Baltic Sea by Sinkkonen and Paasivirta, 2000) were lengthy and highly uncertain, we conducted a sensitivity analysis. In response to doubling sediment half lives of $\mathrm{OCDD} / \mathrm{F}$ and $\mathrm{PCB}-180$, the contribution to total removal by degradation decreased by $11-92 \%$, depending on the contaminant, indicating that the proportion of total loss due to these processes can be very sensitive to degradation rates, which are probably overestimated. In particular, OCDF was the most sensitive to half life adjustments, so we should use caution when assessing this loss process. Alternatively, volatilisation is temperature sensitive and so we ran the model at different temperatures. Volatilisation of PCB-180 increased from 3 to $9 \%$ of total removal for average and summer conditions of 13 and $22{ }^{\circ} \mathrm{C}$, respectively.

Despite the dominance of export as a sediment removal pathway within the northern and central lagoon, total export of contaminants to the Adriatic Sea through the Lido (segment 3), Malamocco (segment 7) and Chioggia (segment 10) inlets was minimal under the "no wind" scenario. Less than $19 \%$ of total $\mathrm{Pb}$ and $\mathrm{Cu}$ loadings and less than $2 \%$ of total PCB-180 and OCDD/F loadings were exported from the Venice Lagoon to the Adriatic Sea (Fig. 4). Minimal export was expected given that Chioggia inlet, which has the largest net export of water, is farthest from the large contaminant loadings in the central basin. OCDD/F, PCB180 export estimates were $0.3,0.2$ and $4.7 \mathrm{~g} \mathrm{y}^{-1}$, respectively, while $\mathrm{Cu}$ and $\mathrm{Pb}$ were estimated at 2.2 and $2.1 \mathrm{t} \mathrm{y}^{-1}$, respectively.

Our estimates of annual export rates to the Adriatic Sea, however, likely underestimated actual losses because episodic flooding events in the lagoon were not included in our model parameterization. In addition, circulation patterns of Solidoro et al. (2004a) used in this study, identified net outflow of water in the Lido and Chioggia inlets while net inflow occurred through the Malamocco inlet. However, recent measurements in 2002 and 2003, suggest that net outflow also occurs in the Malamocco inlet (Gacic et al., 2005).

Ultimately, we found that although substantial sedimentwater exchange occurs, net contaminant loss from the Venice Lagoon for $\mathrm{Pb}$ and $\mathrm{Cu}$ was through burial, while for PCB-180 and $\mathrm{OCDD} / \mathrm{F}$ removal was dominated by degradation within the $20 \mathrm{~cm}$ lower sediment layer followed by burial, resulting in a high persistence of contaminants in the Lagoon. $\mathrm{Pb}$ and $\mathrm{Cu}$ could remain in the water and sediment $(0-20 \mathrm{~cm})$ of the Lagoon for approximately 300 and $270 \mathrm{y}$, respectively. OCDD/F and PCB-180 residence times were 388,61 and $123 \mathrm{y}$, respectively. These long residence times are attributable to the storage within the lower sediment layer $(3-20 \mathrm{~cm})$ which ranged from 44 to $168 \mathrm{y}$.

\section{Conclusions}

Results from a multi-segment fugacity/aquivalence-based model of the Venice Lagoon indicated that the fate of $\mathrm{OCDD} / \mathrm{F}$, PCB-180, $\mathrm{Pb}$ and $\mathrm{Cu}$ in the lagoon is governed by extensive sediment-water exchange of particulate chemical. Simultaneously, contaminants in the water column, most of which are in the particulate phase, circulate throughout the lagoon by advective transport in the water column.

In-place pollution from contaminated sediments located near the industrial area, current industrial discharges, and tributary loadings were identified as the main sources of contaminants to the Lagoon, with negligible contribution from the atmosphere. However, these results are confounded by uncertainty in the fraction of industrial loadings sequestered in the industrial canals and unmeasured loadings from, for example, the City of Venice, boating and shipping.

Source apportionment and contaminant fate analyses suggested that contaminant loadings originating in the central basin circulate amongst all the segments in the northern and central basins but do not reach the far southern basin where, as a consequence, loadings mostly originate from local tributaries. Only a small fraction of contaminant from the dominant loading sources in the central basin reach the Chioggia inlet, through which most water export to the Adriatic Sea occurs, limiting seaward transfer and trapping most of the contaminants in the sediment of the Lagoon under a "no wind" scenario.

\section{Acknowledgements}

Funds for this study were provided by CORILA 2nd Project (2004-2006), research line 3.8 "Speciation, distribution, fluxes, bioaccumulation and toxicity of principal contaminants in the Venice Lagoon: experimental and modelling approach". This is contribution No. 1673 from the Istituto di Scienze Marine, U.O.S di Bologna.

\section{Appendix A. Supplementary information}

Supplementary data associated with this article can be found in the online version at doi:10.1016/j.ecoenv.2009.11.005.

\section{References}

Bellucci, L.G., Frignani, M., Paolucci, D., Ravanelli, M., 2002. Distribution of heavy metals in sediments of the venice lagoon: The role of the industrial area. Sci. Total Environ. 295, 35-49.

Bellucci, L.G., Giuliani, S., Romano, S., Frignani, M., Albertazzi, S., 2007. Suspended particulate matter: Temporal variations, origin and depositional dynamics. In: Campostrini, P. (Ed.), Scientific Research and Safeguarding of Venice - Research Programme 2004-2006. CORILA, Venice, pp. 161-167.

Bhavsar, S.P., Diamond, M.L., Evans, L.J., Gandhi, N., Nilsen, J., Antunes, P., 2004 Development of a coupled metal speciation-fate model for surface aquatic systems. Environ. Toxicol. Chem. 23, 1376-1385.

Bhavsar, S.P., Gandhi, N., Diamond, M.L., Lock, A.S., Spiers, G., De la Torre, M.C.A., 2008. Effects of estimates from different geochemical models on metal fate 
predicted by coupled speciation-fate models. Environ. Toxicol. Chem. 27, 1020-1030.

Capodaglio, G., Personal communication.

Carrer, S., Coffaro, G., Bocci, M., Barbanti, A., 2005. Modelling partitioning and distribution of micropollutants in the Lagoon of Venice: A first step towards a comprehensive ecotoxicological model. Ecol. Model. 184, 83-101.

Carrer, S., Leardi, R., 2006. Characterizing the pollution produced by an industrial area - chemometric methods applied to the Lagoon of Venice. Sci. Total Environ. 370, 99-116.

Collavini, F., Bettiol, C., Zaggia, L., Zonta, R., 2005. Pollutant loads from the drainage basin to the Venice Lagoon (Italy). Environ. Int. 31, 939-947.

Dalla Valle, M., Marcomini, A., Sfriso, A., Sweetman, A.J., Jones, K.C., 2003. Estimation of $\mathrm{PCDD} / \mathrm{F}$ distribution and fluxes in the Venice Lagoon, Italy: Combining measurement and modelling approaches. Chemosphere 51, 603-616.

Degetto, S., Cantaluppi, C., 2004. Radiochemical methodology for the determination of the mass balance of suspended particulate materials exchanged at the inlets of the Venice Lagoon. J. Marine Syst. 51, 77-94.

Diamond, M.L., Mackay, D., Welbourn, P.M., 1992. Models of multimedia partitioning of multispecies chemicals - the fugacity equivalence approach. Chemosphere 25, 1907-1921.

Diamond, M.L., 1995. Application of a mass-balance model to assess in-place arsenic pollution. Environ. Sci. Technol. 29, 29-42.

Diamond, M.L., 1999. Development of a fugacity/aquivalence model of mercury dynamics in lakes. Water Air Soil Poll. 111, 337-357.

Ferrari, G., personal communication.

Frignani, M., Bellucci, L. G., 1999. Cronologia della contaminazione di sedimenti della laguna di venezia. Final report. Istituto di Geologia Marina, C.N.R, Bologna.

Frignani, M., Bellucci L. G., Albertazzi, S., 1999. Project “Orizzonte 2023” Section C. Magistrato alle Acque di Venezia - Consorzio Venezia Nuova, Venice.

Frignani, M., Bellucci, L.G., Carraro, C., Raccanelli, S., 2001. Polychlorinated biphenyls in sediments of the Venice Lagoon. Chemosphere 43, 567-575.

Frignani, M., Bellucci, L.G., Carraro, C., Favotto, M., 2004. Accumulation of polychlorinated biphenyls in sediments of the Venice Lagoon and the industrial area of Porto Marghera. Chemosphere 54, 1563-1572.

Frignani, M., Bellucci, L.G., Favotto, M., Albertazzi, S., 2005. Pollution historical trends as recorded by sediments at selected sites of the Venice Lagoon. Environ. Int. 31, 1011-1022.

Gacic, M., Mazzoldi, A., Kovacevic, V., Cosoli, S., Mancero Mosquera, I., Arena, F., Cardin, V., 2005. Water fluxes in Venice Lagoon inlets and coastal circulation. In: Campostrini, P. (Ed.), Scientific Reasearch and Safeguarding of Venice. 2003 results. CORILA, Venice.

Gambaro, A., Manodori, L., Moret, I., Capodaglio, G., Cescon, P., 2004. Determination of polychlorobiphenyls and polycyclic aromatic hydrocarbons in the atmospheric aerosol of the venice lagoon. Anal. Bioanal. Chem. 378, 1806-1814.

Gerino, M., Frignani, M., Mugnai, C., Bellucci, L.G., Prevedelli, A., Valentini, A. Castelli, A., Delmotte, S., Sauvage, S., 2007. Bioturbation in the Venice Lagoon: Rates and relationship to organisms. Acta Oecol. 32, 14-25.

Giani, M., Personal communication.

Guerzoni, S., Rossini, P., Molinaroli, E., Rampazzo, G., Raccanelli, S., 2004. Measurement of atmospheric deposition of polychlorinated dibenzo-p-dioxins and dibenzofurans in the Lagoon of Venice, Italy. Chemosphere 54, 1309-1317.

Guerzoni, S., Rossini, P. Sarretta, A., Raccanelli, S., Ferrari, G., Molinaroli, E, 2007. POPs in the Lagoon of Venice: Budgets and pathways. Chemosphere 67, 1776-1785.

Harner, T., Green, N.J.L., Jones, K.C., 2000. Measurements of octanol-air partition coefficients for PCDD/F: A tool in assessing air-soil equilibrium status. Environ. Sci. Technol. 34, 3109-3114.

Lucchini, F., Frignani, M., Sammartino, I., Dinelli, E., Bellucci, L.G., 2001/2002. Composition of Venice Lagoon sediments: Distribution, sources, settings and recent evolution. GeoActa $1,1-14$.

Mackay, D., Paterson, S., Joy, M., 1983. A quantitative water, air, sediment interaction (QWASI) fugacity model for describing the fate of chemicals in rivers. Chemosphere 12, 1193-1208.

Mackay, D., Diamond, M., 1989. Application of the QWASI (quantitative water air sediment interaction) fugacity model to the dynamics of organic and inorganic chemicals in lakes. Chemosphere 18, 1343-1365.

Mackay, D., Ying Shiu, W., Ching, Ma, K., 1992. In: Illustrated Handbook of Physical-Chemical Properties and Environmental Fate for Organic Chemicals. Lewis Pubishers, Boca Raton.

Mackay, D., 2001. In: Multimedia Environmental Models: The Fugacity Approach. Lewis Publishers, Boca Raton.

Manodori, L., Gambaro, A., Piazza, R., Ferrari, S., Stortini, A.M., Moret, I., Capodaglio, G., 2006. PCBs and PAHs in sea-surface microlayer and sub-surface water samples of the Venice Lagoon (Italy). Mar Pollut Bull 52, 184-192.
Manodori, L., Gambaro, A., Moret, I., Capodaglio, G., Cescon, P., 2007. Air-sea gaseous exchange of PCB at the Venice Lagoon (Italy). Mar. Pollut. Bull. 54, $1634-1644$.

MAV, 2000. The mapping of the pollutants in the lagoon bottom sediments (in Italian). Final report. Consorzio Venezia Nuova, Venice.

MAV, 2006. MELa1 (Monitoraggi Ecosistema Lagunare 1). Consorzio Venezia Nuova, Venice.

MAV-SAMA, 2004. Qualità delle acque e degli scarichi idrici dell'area di Porto Marghera. Dati relativi al 2001-2002. Sezione Antinquinamento del Magistrato alle Acque, Venice.

Micheletti, C., Critto, A., Marcomini, A., 2007. Assessment of ecological risk from bioaccumulation of PCDD/Fs and dioxin-like PCBs in a coastal lagoon. Environ. Int. 33, 45-55.

Orel, G., Boatto, V., Sfriso, A., Pellizzato, M., 2000. Fishing sources management plan for the lagoons of the Venice Province (in Italian), Provincia di Venezia.

Rossini, P., Guerzoni, S., Molinaroli, E., Rampazzo, G., De Lazzari, A., Zancanaro, A., 2005. Atmospheric bulk deposition to the Lagoon of Venice - part I. Fluxes of metals, nutrients and organic contaminants. Environ. Int. 31, 959-974.

Schenker, U., MacLeod, M., Scheringer, M., Hungerbuhler, K., 2005. Improving data quality for environmental fate models: A least-squares adjustment procedure for harmonizing physicochemical properties of organic compounds. Environ. Sci. Technol. 39, 8434-8441.

Secco, T., Pellizzato, F., Sfriso, A., Pavoni, B., 2005. The changing state of contamination in the Lagoon of Venice. Part 1: Organic pollutants. Chemosphere 58, 279-290.

Sfriso, A., Facca, C., Ghetti, P.F., 2003. Temporal and spatial changes of macroalgae and phytoplankton in a Mediterranean coastal area: The Venice Lagoon as a case study. Mar. Environ. Res. 56, 617-636.

Sfriso, A., Facca, C., Marcomini, A., 2005a. Sedimentation rates and erosion processes in the Lagoon of Venice. Environ. Int. 31, 983-992.

Sfriso, A., Facca, C., Ceoldo, S., Pessa, G., 2005b. Sedimentation rates, erosive processes, grain-size and sediment density changes in the Lagoon of Venice. In:(Eds). Scientific Research and Safeguarding of Venice. 2003 results. CORILA, Venice.

Shiu, W.Y., Ma, K.C., 2000. Temperature dependence of physical-chemical properties of selected chemicals of environmental interest. II. Chlorobenzenes, polychlorinated biphenyls, polychlorinated dibenzo-p-dioxins, and dibenzofurans. J. Phys. Chem. Ref Data 29, 387-462.

Sinkkonen, S., Paasivirta, J., 2000. Degradation half-life times of PCDDs, PCDFs and PCBs for environmental fate modeling. Chemosphere 40, 943-949.

Solidoro, C., Canu, D.M., Cucco, A., Umgiesser, G., 2004a. A partition of the Venice Lagoon based on physical properties and analysis of general circulation. J. Marine Syst. 51, 147-160.

Solidoro, C., Pastres, R., Cossarini, G., Ciavatta, S., 2004b. Seasonal and spatial variability of water quality parameters in the Lagoon of Venice. J. Marine Syst. 51, 7-18.

Sommerfreund, J. K., Arhonditsis, G. B., Diamond, M., Frignani, M., Capodaglio, G. Gerino, M., Bellucci, L. G., Giuliani, S., Mugnai, C., 2009. Examination of the uncertainty in contaminant fate and transport modelling: A case study in the Venice Lagoon. Ecotoxicol. Environ. Saf.. 10.1016/j.ecoenv.2009.05.008.

Stiver, W., Mackay, D., 1989. The linear additivity principle in environmental modeling - application to chemical behavior in soil. Chemosphere 19, 1187-1198.

Tipping, E., 1998. Humic ion-binding model VI: An improved description of the interactions of protons and metal ions with humic substances. Aquat. Geochem. 4, 3-48.

Umgiesser, G., Canu, D.M., Cucco, A., Solidoro, C., 2004. A finite element model for the Venice Lagoon. Development, set up, calibration and validation. J. Marine Syst. 51, 123-145.

USEPA, Environmental Protection Agency 2005. Partition coefficients for metals in surface water, soil and waste. EPA/600/R-05/074 Accessed July 2009 at <http://www.epa.gov/athens/publications/reports/Ambrose600R05074Parti tionCoefficients.pdf $\rangle$.

Valsaraj, K.T., Thoma, G.J., Porter, C.L., Reible, D.D., Thibodeaux, L.J., 1993. Transport of dissolved organic carbon-derived natural colloids from bed sediments to overlying water - laboratory simulations. Water Sci. Technol. 28, $139-147$.

Valsaraj, K.T., Verma, S., Sojitra, I., Reible, D.D., Thibodeaux, L.J., 1996. Diffusive transport of organic colloids from sediment beds. J. Environ. Eng.-ASCE 122, $722-729$.

Wang, X.S., Matisoff, G., 1997. Solute transport in sediments by a large freshwater oligochaete, Branchiura sowerbyi. Environ. Sci. Technol. 31, 1926-1933.

Wijsman, J.W.M., Herman, P.M.J., Middelburg, J.J., Soetaert, K., 2002. A model for early diagenetic processes in sediments of the continental shelf of the black sea. Estuar. Coast Shelf S 54, 403-421. 